\title{
ESTIMATION OF THE SHARE OF WOMEN IN THE NUMBER OF STUDENTS OF HIGHER EDUCATIONAL INSTITUTIONS: DATA BY REGIONS OF RUSSIA
}

\author{
Iuliia Pinkovetskaia (D) 1
}

\begin{abstract}
The purpose of our study was to evaluate the indicators characterizing the gender structure of students of higher education institutions in the regions of Russia. These indicators were the proportion of women among students studying at higher education institutions in 2017-2020. The study used official statistical information for 82 regions of Russia. We used the density functions of the normal distribution as models. The results of the computational experiment showed that, on average, there was a feminization of higher education in the regions, since the share of women in the number of students was in the range from $52 \%$ to $55 \%$. At the same time, in the majority $(68 \%)$ of regions, the number of female students exceeded the number of male students. The proposed methodological approach and the results obtained have a scientific novelty, since the assessment of the territorial features of the gender structure of students in the regions of Russia has not been carried out before.
\end{abstract}

Palavras-chave: Higher Education; Percentage of Female Students; Regions of Russia; Functions of Normal Distribution.

\section{ESTIMATIVA DA PROPORÇÃO DE MULHERES NO NÚMERO DE ESTUDANTES DE INSTITUIÇÕES DE ENSINO SUPERIOR: DADOS SOBRE AS REGIÕES DA RÚSSIA}

\section{Resumo}

O objetivo do nosso estudo foi avaliar os indicadores que caracterizam a estrutura de gênero de estudantes de instituições de ensino superior nas regiões da Rússia. Essas taxas corresponde à proporção de mulheres entre os estudantes matriculados em instituições de ensino superior em 2017-2020. O estudo utilizou informações estatísticas oficiais sobre 82 regiões da Rússia. Usamos funções de densidade de distribuição normal como modelos. Os resultados do experimento computacional mostraram que, em média, a feminização do ensino superior foi observada por região, uma vez que a proporção de mulheres na população estudantil estava na faixa de $52 \%$ a $55 \%$. Ao mesmo tempo, na maioria (68\%) das regiões, o número de estudantes do sexo feminino excedeu o número de estudantes do sexo masculino. A abordagem metodológica proposta e os resultados obtidos 
apresentam novidade científica, uma vez que a avaliação das características territoriais da estrutura de gênero dos jovens estudantes nas regiões da Rússia não foi realizada anteriormente.

Keywords: Ensino Superior; Porcentagem de Estudantes; Regiões da Rússia; Funções de Distribuição Normal.

\section{Introduction}

In the twentieth century male students dominated in the higher education system of most countries. At the beginning of the twenty-first century, this gap has not only narrowed, but the opposite trend is also observed. In 2010, women dominated among people who received higher education in many countries (Barro, and Lee 2010). Currently, an increasing number of women who have received secondary education are seeking higher education. Thus, in the member countries of the Organization for Economic Cooperation and Development (OECD), the proportion of women among those enrolled in higher education programs in 2018 was 54\%. The greatest increase (about 60\%) in the feminization of students was observed in the Czech Republic, Iceland and Sweden (Why do more young women 2021). The same document notes that the availability of higher education for women allows them to expect to receive a higher salary (almost 1.5 times) compared to women with secondary education. In addition, statistics show that unemployment is less pronounced among women with higher education.

Our study was devoted to the assessment of the existing gender differences in the structure of students of higher education institutions. The study of the current level of this phenomenon is important both for the state bodies regulating the higher education system, and directly for potential students. Our article responds to the calls made in a number of scientific publications (for example, Pekkarinen 2012; Stoet, and Geary 2020), to study the existing features of the distribution of students enrolled in higher education programs by gender groups.

Despite the existence of researches on the problem of the gender structure of students enrolled in higher education programs, not enough attention has been paid to the regional peculiarities of studying this problem so far. The presence of organizations in the regions that teach students according to the relevant programs, as indicated in the works (Abel, and Deitz 2011; Ciriaci 2014), increases the attractiveness of the regions, positively affects their economic growth and, most importantly, ensures the retention of school graduates in the regional labor market. All this determines the increased interest in studying the regional peculiarities of the ratio of the number of female and male students studying at higher education institutions.

To date, the sphere of higher education in Russia has received significant development. In 2020, there were 1259 specialized organizations working in this industry. The total number of students studying at universities 
and other higher educational institutions was 4049333 (Federal State Statistics Service 2021).

The purpose of our study was to evaluate the indicators characterizing the gender structure of students of higher education institutions in the regions of Russia. Our article is aimed at obtaining a certain empirical and methodological contribution to the knowledge about the presence of the proportion of women in the total number of students enrolled in higher education programs. This contribution consists in the fact that the author's method of modeling the assessment of the corresponding indicators for the regions of Russia using the density functions of the normal distribution is proposed. The empirical contribution is related to the determination of the average values and standard deviations by region of such indicators as the proportion of women among students studying at higher education institutions. In addition, the regions with the maximum and minimum values of these indicators are determined.

The structure of this work is given below. The next section presents an overview of scientific publications of recent years that characterize such aspects of higher education as the gender structure of students in the regions of Russia. The methodology, initial data and design of the study described in our article are presented below. The following sections present the simulation results and their discussion. The last sections contain conclusions and bibliographic references.

\section{Literature review}

A number of scientific publications published in recent years have been devoted to the problem of assessing such an aspect of the higher education system in Russia as the gender structure of students studying at higher education institutions. A brief description of these publications is given in table 1.

Table 1: Scientific publications describing the activities of scientific and pedagogical staff

\begin{tabular}{|c|c|}
\hline Authors & Problems under study \\
\hline $\mathbf{1}$ & $\mathbf{2}$ \\
\hline $\begin{array}{c}\text { Dzampayeva } \\
\text { (2016) }\end{array}$ & $\begin{array}{c}\text { The feminization of higher education is studied on the } \\
\text { example of the North Caucasus Mining and } \\
\text { Metallurgical Institute for the period from 1986 to } \\
2016 . \text { An increase in the proportion of female } \\
\text { teachers, especially those with a PhD degree, is } \\
\text { shown }\end{array}$ \\
\hline Makarova (2018) & $\begin{array}{c}\text { The gender features of the student body in Russia } \\
\text { and the gender-sectoral structure of training in higher }\end{array}$ \\
\hline
\end{tabular}




\begin{tabular}{|c|c|}
\hline & education institutions are considered \\
\hline Ostapenko (2010) & $\begin{array}{l}\text { The gender asymmetry of students studying at } \\
\text { Russian state universities is evaluated. The } \\
\text { conclusion is made about a small predominance of } \\
\text { the proportion of female students }\end{array}$ \\
\hline Shishlova (2015) & $\begin{array}{l}\text { The article examines the gender features of } \\
\text { communicative and interpersonal relations in the } \\
\text { process of obtaining higher education for men and } \\
\text { women. The absence of gender inequality is shown. }\end{array}$ \\
\hline Karmaeva (2020) & $\begin{array}{l}\text { The study of the probability of obtaining higher } \\
\text { education for women and men born in } 1954-1986 \\
\text { based on a survey of } 3,820 \text { respondents. The } \\
\text { assumption that women are more likely to receive } \\
\text { higher education in Russia than men is confirmed. }\end{array}$ \\
\hline $\begin{array}{l}\text { Cherednichenko } \\
\text { (2018) }\end{array}$ & $\begin{array}{l}\text { The analysis of the dynamics of the total number of } \\
\text { students in higher education organizations is carried } \\
\text { out. It allowed us to conclude that the proportion of } \\
\text { women among students increased from } 56.7 \% \text { in } \\
2000 \text { to } 58.2 \% \text { in } 2005 \text {. In the following years, } \\
\text { however, this trend reversed and the proportion of } \\
\text { female students began to decrease }\end{array}$ \\
\hline $\begin{array}{c}\text { Talina, and } \\
\text { Karnaukhov (2017) }\end{array}$ & $\begin{array}{c}\text { Gender differences in the number of students } \\
\text { belonging to different levels of post-secondary } \\
\text { education were studied. The presence of a gender } \\
\text { gap is shown }\end{array}$ \\
\hline Baskakova (2005) & $\begin{array}{l}\text { The article presents an assessment of the proportion } \\
\text { of women in the total number of students of public } \\
\text { and private institutions of higher education in Russia } \\
\text { for the period from } 1991 \text { to } 2002 \text {. The growth of this } \\
\text { indicator from } 51 \% \text { to } 57 \% \text { is shown. }\end{array}$ \\
\hline $\begin{array}{l}\text { Rylskaya, and } \\
\text { Moshkina (2020) }\end{array}$ & $\begin{array}{c}\text { The article presents an assessment of the gender } \\
\text { characteristics of obtaining higher education based on } \\
\text { a survey of } 147 \text { students of the South Ural State } \\
\text { University. It is shown that the majority of students } \\
\text { have gender equality in the learning process. }\end{array}$ \\
\hline $\begin{array}{l}\text { Konstantinovskiy, } \\
\text { Voznesenskaya, } \\
\text { and } \\
\text { Cherednichenko } \\
\text { (2014) }\end{array}$ & $\begin{array}{c}\text { According to the data for } 2008 \text {, the predominance of } \\
\text { women among students of higher education } \\
\text { institutions is shown }\end{array}$ \\
\hline
\end{tabular}

Source: The table is compiled by the author on the basis of the information provided in the RSCI (Science electronic library 2021).

Based on the information given in Table 1, it can be stated that the problem of studying the gender structure of students who studied under higher education programs is relevant in Russia. In most of the studies reviewed, this 
problem was studied in Russia as a whole. At the same time, a comprehensive assessment of the distribution of the gender structure of students in all regions of Russia has not been sufficiently reflected in scientific publications. Taking this into account, it seems appropriate to conduct a comparative analysis of the existing relative (specific) indicators characterizing the achieved level of feminization of students in all regions of Russia.

\section{Methodology and design}

Our article examines the indicators that characterize the share of women in the total number of students in higher education institutions in the regions of Russia. At the same time, empirical data on the preparation of students in 2017-2020 for bachelor's degree programs (four years of study), specialty degree (five years of study), as well as for master's degree programs are considered.

The research process included five stages. At the first stage, the initial data describing the number and gender structure of students enrolled in higher education programs in 2017, 2018, 2019 and 2020 were formed. At the second stage, the values of the specific weights of the number of female students in the total number of students for each of the regions were calculated. At the third stage, the distribution of indicators by region was evaluated based on the development of mathematical models. At the fourth stage, the average values of indicators for the regions of Russia were determined, as well as the ranges in which the values of these indicators are located for most of them. At the fifth stage, the regions that were characterized by the maximum and minimum values of indicators according to the data of 2020 were determined.

The study used official statistical information of the Ministry of Science and Higher Education of the Russian Federation for 2017-2020 on the number and gender structure of students studying at higher education institutions in 82 regions of Russia (Official statistical information on additional professional and higher education 2021).

In our study, the following hypotheses were tested:

hypothesis 1 - for the period from 2017 to 2020, there was a slight decrease in the proportion of women in the total number of students;

hypothesis 2 - in most regions of Russia, women predominate in the number of students enrolled in higher education programs, that is, there is a feminization of education;

hypothesis 3 - the values of the indicators characterizing the share of women in the total number of students differ by region, however, the coefficient of variation for each of the four indicators by region does not exceed $33 \%$;

hypothesis 4 - the regions characterized by the maximum and minimum values of the proportion of female students in higher education institutions are located in different federal districts. 
The evaluation of the values of the four considered indicators was carried out on the basis of economic and mathematical modeling of the initial empirical data. As models, we used the density functions of the normal distribution, the method of developing which for estimating the values of relative cost indicators was proposed by the author. Some aspects of the use of the methodology are given in the works (Pinkovetskaia and Slepova 2018; Pinkovetskaia et al. 2021). During the development of the functions, the initial empirical data were grouped according to the ranges of changes in the values of the indicators. These data groups can be geometrically represented in the form of corresponding histograms. Data approximation using normal distribution functions was carried out using generally accepted statistical methods. It is important to note that the average values of the considered indicators, as well as their standard deviations for the density functions of the normal distribution, were displayed in the formulas of the developed functions themselves. Therefore, by constructing a specific function, we get the specified parameters of the considered indicators without additional calculations.

The Pearson test is based on grouped data (reflected in the histogram) and allows you to compare the empirical distribution describing a specific indicator of a set of objects in regions with the corresponding distribution density function. The criterion answers the question of whether different values of the indicator occur with the same frequency in empirical and theoretical distributions. The greater the discrepancy between these two distributions, the greater the empirical value of the Pearson criterion. It should be noted that for histograms with 7 intervals (which are most often used), the tabular values of the Pearson agreement criterion are 9.49. We also propose to use the Kolmogorov-Smirnov quality criterion to compare two distributions: empirical and theoretical. It is based on determining the sum of accumulated discrepancies between two such distributions. If the differences between them are insignificant and do not reach a critical value, then this is the basis for recognizing the high quality of the approximation. If the empirical value is less than the critical value, then it can be concluded that the distribution density function approximates the initial empirical data well. When considering distribution density functions describing indicators for all 82 regions of Russia and a significance level of 0.05 , the critical value of the Kolmogorov-Smirnov quality criterion is 0.174 . The Shapiro-Wilk quality criterion is based on the assumption that the values of the distribution characteristics are unknown in advance. The minimum number of empirical data required for verification by this criterion is eight. With a high significance level of 0.01 , the tabular value of the Shapiro-Wilk agreement criterion is 0.93 . Thus, functions for which this criterion is higher than 0.93 have good quality. The verification of empirical data on the above three criteria is based on different principles and uses different methods. Given this, an integrated approach using simultaneous consideration of the density functions of the normal distribution in accordance with these three criteria is able to assess the quality of these functions with a high degree of confidence. 
The obtained functions allowed us to determine the average values of each of the four indicators for the regions under consideration, as well as the ranges of their changes characteristic of most regions. In addition, the study identified regions in which the considered indicators have values above the upper and below the lower boundaries of the ranges. The boundaries of the indicator ranges for $68 \%$ of the regions were determined based on the average values of the indicators and the corresponding standard deviations. The lower bound of the interval is equal to the difference between the mean and the standard deviation, and the upper bound is equal to their sum.

\section{Modeling and results}

In the course of the computational experiment, economic and mathematical modeling was carried out on the basis of empirical data. The models that describe the distributions $\left(y_{1} ; y_{2} ; y_{3} ; y_{4}\right)$ of the four indicators $\left(x_{1}, \% ; x_{2}, \% ; x_{3}, \% ; x_{4}, \%\right)$ across all 82 Russian regions are shown below:

- the proportion of women among students studying at higher education institutions in 2017

$$
y_{1}\left(x_{1}\right)=\frac{410.24}{4.20 \times \sqrt{2 \pi}} \cdot e^{-\frac{\left(x_{1}-54.32\right)^{2}}{2 \times 4.20 \times 4.20}}
$$

- the proportion of women among students studying at higher education institutions in 2018

$$
y_{2}\left(x_{2}\right)=\frac{468.57}{4.45 \times \sqrt{2 \pi}} \cdot e^{-\frac{\left(x_{2}-53.90\right)^{2}}{2 \times 4.45 \times 4.45}} ;
$$

- the proportion of women among students studying at higher education institutions in 2019

$$
y_{3}\left(x_{3}\right)=\frac{468.57}{4.54 \times \sqrt{2 \pi}} \cdot e^{-\frac{\left(x_{3}-53.20\right)^{2}}{2 \times 4.54 \times 4.54}}
$$

- the proportion of women among students studying at higher education institutions in 2020

$$
y_{4}\left(x_{4}\right)=\frac{398.29}{4.25 \times \sqrt{2 \pi}} \cdot e^{-\frac{\left(x_{4}-52.69\right)^{2}}{2 \times 4.25 \times 4.25}} \text {. }
$$

The quality of functions (1)-(4) we tested using such criteria: by the Kolmogorov-Smirnov, the Pearson and the Shapiro-Wilk. Calculated values of criteria are given in Table 2. 
Table 2: Calculated values of criteria

\begin{tabular}{|c|c|c|c|}
\hline \multirow{2}{*}{ Indicators } & \multicolumn{2}{c|}{ Criteria } \\
\cline { 2 - 4 } & $\begin{array}{c}\text { The } \\
\text { Kolmogorov- } \\
\text { Smirnov test } \\
\text { Pearson } \\
\text { test }\end{array}$ & $\begin{array}{c}\text { The } \\
\text { Shapiro- } \\
\text { Wilk test }\end{array}$ \\
\hline $\begin{array}{c}\text { the proportion of women } \\
\text { among students studying at higher } \\
\text { education institutions in 2017 }\end{array}$ & 0.05 & 2.37 & 0.97 \\
\hline $\begin{array}{c}\text { the proportion of women among } \\
\text { students studying at higher } \\
\text { education institutions in 2018 }\end{array}$ & 0.04 & 2.39 & 0.97 \\
\hline $\begin{array}{c}\text { the proportion of women among } \\
\text { students studying at higher } \\
\text { education institutions in 2019 }\end{array}$ & 0.05 & 3.38 & 0.96 \\
\hline $\begin{array}{c}\text { the proportion of women among } \\
\text { students studying at higher } \\
\text { education institutions in 2020 }\end{array}$ & 0.03 & 1.48 & 0.98 \\
\hline
\end{tabular}

Source: The data in the table are based on the results of calculated functions.

Information given in column 2 of Table 2 showed that all calculated values are less than the critical value by the Kolmogorov-Smirnov test $(0.174)$ at significant level equal 0.05 . Data in column 3 are less than critical value of Pearson criterion (9.49). Data in column 4 exceed critical value 0.93 ShapiroWilk test with significant level of 0.01 . Thus, the computational experiment showed that two developed functions have high quality.

At the next stage of the study, the values of indicators characterizing the proportion of women in the total number of students studying at higher education institutions in the regions of Russia were determined. The values of the indicators, the average by region, are shown in column 2 of Table 3 . The average values were determined on the base of functions (1)-(4). The third column indicates the standard deviation for discussing indicators. The values of the indicators characterizing the upper and lower boundaries of the intervals corresponding to the majority of regions are shown in column 4 . We calculate the lower limits as the difference between the average value and the standard deviation, and we calculate the upper limits as the sum of the average value and the standard deviation. 


\begin{tabular}{|c|c|c|c|}
\hline Indicator numbers & $\begin{array}{c}\text { Average } \\
\text { values }\end{array}$ & $\begin{array}{l}\text { Standard } \\
\text { deviation }\end{array}$ & $\begin{array}{c}\text { Values for } \\
\text { most regions }\end{array}$ \\
\hline 1 & 2 & 3 & 4 \\
\hline $\begin{array}{l}\text { the proportion of women among } \\
\text { students studying at higher } \\
\text { education institutions in } 2017\end{array}$ & 54.32 & 4.20 & $50.12-58.52$ \\
\hline $\begin{array}{l}\text { the proportion of women among } \\
\text { students studying at higher } \\
\text { education institutions in } 2018\end{array}$ & 53.90 & 4.45 & $49.45-58.35$ \\
\hline $\begin{array}{l}\text { the proportion of women among } \\
\text { students studying at higher } \\
\text { education institutions in } 2019\end{array}$ & 53.20 & 4.54 & $48.66-57.74$ \\
\hline $\begin{array}{l}\text { the proportion of women among } \\
\text { students studying at higher } \\
\text { education institutions in } 2020\end{array}$ & 52.69 & 4.25 & $48.44-56.94$ \\
\hline
\end{tabular}

Source: The calculations are carried out by the author on the basis of functions (1)-(4).

\section{Discussion}

An analysis of empirical data for 2017-2020 showed that higher education institutions are available in all 82 regions of Russia. Female students studied in higher education organizations in all regions. The total number of female students in 2017 was 2279605, in 2018 - 2225643, in 2019 2155251, in 2020 - 2127113. At the same time, the number of female students enrolled in higher education programs differed significantly in different regions. The minimum number (less than two thousand nine hundred) of female students was in such regions as Altai republic, Kamchatka territory, Sakhalin region, Magadan region, Jewish autonomous region, Chukotka autonomous district. The maximum number (more than sixty-one thousand women students) was in the following regions: Sverdlovsk region, Rostov region, Tatarstan republic, St. Petersburg and Moscow cities.

The regional average value of proportion of women among students studying at higher education institutions in 2017 was $54.3 \%$. In most regions, the value of this indicator was in the range from $50.1 \%$ to $58.5 \%$. The average value of the same indicator according to the data for 2018 was $53.9 \%$, the interval of its change in most regions is from $49.4 \%$ to $58.4 \%$. The average proportion of women among students studying at higher education institutions in 2019 was $53.2 \%$. At the same time, the range of changes in the indicator values for most regions was $48.6 \%-57.7 \%$. The average value of the corresponding indicator according to the data for 2020 was $52.7 \%$, the interval of its change in most regions is from $48.4 \%$ to $56.9 \%$. A comparison of the 
average values of the indicators allowed us to conclude that the share of women in the total number of students decreased slightly over the period from 2017 to 2020. This decrease was $1.6 \%(54.3 \%-52.7 \%)$. Thus, the first hypothesis was confirmed.

The analysis showed that the average share of women in the total number of students for all the years under review was more than $52 \%$, but less than $55 \%$. That is, more than half of the students were women. It should be noted that there were certain differences in the feminization of higher education in the regions of Russia. Thus, in 2020 in ten regions of Russia, the proportion of female students was less than $49 \%$, that is, there were more male students in these regions. These regions included: Chukotka autonomous district, Adygea republic, Murmansk region, Bryansk region, Belgorod region, Sevastopol city, Komi republic, Karachay-Cherkess republic, North OssetiaAlania republic, Rostov region. Approximately equal proportions of women and men among students were observed in sixteen regions: Dagestan republic, Ivanovo region, Kabardino-Balkar republic, Tomsk region, Tula region, Ulyanovsk region, Astrakhan region, Magadan region, Kamchatka territory, Chechen republic, Vladimir region, Samara region, Krasnodar territory, Tambov region, Kalmykia republic, Primorsky territory. In the remaining fiftysix regions, the proportion of female students was higher compared to the same indicator for male students. Consequently, in $68 \%$ of all Russian regions, there was a feminization of students in higher educational institutions, that is, the second hypothesis was confirmed.

The next step was to determine the regions of Russia in which the maximum and minimum values of each indicator were marked. In this case, the maximum values are those that exceed the upper limits of the ranges specified in column 4 of Table 3, and the minimum values are those that are less than the lower limits of the specified ranges. The results of this analysis in 2020 are shown in Table 4. For 2017-2019, the corresponding values are not given in the article, since the list of regions with maximum and minimum values for this period is similar to 2020. There are only small differences in the values of indicators by regions. Along with the lists of regions, this table also shows the values of indicators by region, as well as which of the federal districts the regions belong to.

Table 4: Characteristics of Russian regions with maximum and minimum indicator values

\begin{tabular}{|c|c|c|c|}
\hline Indicators & Region & Value & $\begin{array}{c}\text { Federal } \\
\text { district }\end{array}$ \\
\hline $\mathbf{1}$ & $\mathbf{2}$ & $\mathbf{3}$ & $\mathbf{4}$ \\
\hline \multirow{2}{*}{\begin{tabular}{c} 
the proportion of \\
women among \\
students studying \\
\cline { 2 - 4 } $\begin{array}{c}\text { at higher } \\
\text { education }\end{array}$
\end{tabular}} & Waroslavl region & $56.95 \%$ & Central \\
\cline { 2 - 4 } & Orenburg region & $57.38 \%$ & South \\
\cline { 2 - 4 } & Crimea Republic & $57.43 \%$ & Privolzhsky \\
\hline
\end{tabular}




\begin{tabular}{|c|c|c|c|}
\hline \multirow{18}{*}{$\begin{array}{l}\text { institutions in } \\
2020\end{array}$} & Novgorod region & $57.81 \%$ & North-West \\
\hline & Krasnodar territory & $57.87 \%$ & South \\
\hline & Khakassia republic & $59.32 \%$ & Siberian \\
\hline & Leningrad region & $60.25 \%$ & North-West \\
\hline & Tyva republic & $61.87 \%$ & Siberian \\
\hline & Altai republic & $62.30 \%$ & Siberian \\
\hline & $\begin{array}{c}\text { Jewish autonomous } \\
\text { region }\end{array}$ & $63.07 \%$ & Far Eastern \\
\hline & \multicolumn{3}{|c|}{ With minimum values of indicators } \\
\hline & $\begin{array}{c}\text { Chukotka autonomous } \\
\text { district }\end{array}$ & $21.58 \%$ & Far Eastern \\
\hline & Adygea republic & $43.40 \%$ & $\begin{array}{c}\text { North } \\
\text { Caucasian }\end{array}$ \\
\hline & Murmansk region & $44.79 \%$ & North-West \\
\hline & Bryansk region & $45.83 \%$ & Central \\
\hline & Belgorod region & $47.34 \%$ & Central \\
\hline & Sevastopol city & $47.51 \%$ & South \\
\hline & Komi republic & $47.63 \%$ & North-West \\
\hline & $\begin{array}{c}\text { Karachay-Cherkess } \\
\text { Republic }\end{array}$ & $47.68 \%$ & $\begin{array}{c}\text { North } \\
\text { Caucasian }\end{array}$ \\
\hline & $\begin{array}{c}\text { Republic of North } \\
\text { Ossetia-Alania }\end{array}$ & $48.21 \%$ & $\begin{array}{c}\text { North } \\
\text { Caucasian }\end{array}$ \\
\hline & Rostov region & $48.85 \%$ & South \\
\hline
\end{tabular}

Source: Developed by the author on the basis of data from Table 3.

Table 4 provides information on the values of indicators for each of the regions (column 3 ), as well as their territorial location (column 4 ). The analysis of this information showed that there is no connection between the maximum and minimum values of the indicators and the territorial location of the regions. That is, the regions with high and low values of indicators are located in different federal districts. Thus, we can state the confirmation of forth hypothesis.

The data of the fourth table allows us to draw a conclusion about the differentiation of the values of indicators by region. In addition, the degree of variation of each of the indicators presented in Table 3 was analyzed. For this purpose, we used the standard deviations shown in column 3 . The variation indices are as follows: for the first indicator $-7.71 \%$, for the second indicator $-8.26 \%$, for the third indicator $-8.53 \%$, for the fourth indicator $-8.07 \%$. This analysis showed that in the regions under consideration, the level of differentiation of the values of all four indicators was less than $33 \%$. That is, the third hypothesis was confirmed.

\section{Conclusion}

In general, it should be noted that our research makes a number of important contributions to the knowledge of the territorial features of the (c) (1) 8

Perspectivas em Diálogo, Naviraí, v. 09, n. 19, p. 07-20, jan./abr. 2022. 
gender structure of students in the higher education system in Russia. The purpose of our study was to evaluate the indicators characterizing the gender structure of students of higher education institutions in the regions of Russia. The conclusions that have scientific novelty and originality are given below. First, it was found that female students studied in 2017-2020 at institutes of higher education located in all 82 regions of Russia without exception. Accordingly, they could study in an accessible proximity to their place of residence. In the course of the study, a method was proposed for evaluating four indicators that characterize the gender structure of students in the higher education system, using the density functions of the normal distribution. Based on the proposed methodology, the distribution of indicators for 2017-2020 was estimated for 82 regions of Russia. The results of the computational experiment showed that, on average, there was a feminization of higher education in the regions, since the share of women in the number of students was in the range from $52 \%$ to $55 \%$. At the same time, in the majority $(68 \%)$ of regions, the number of female students exceeded the number of male students.

There was a certain differentiation of the values of the four indicators by region. At the same time, the coefficient of variation of the values of the indicators was in the range from $7.7 \%$ to $8.5 \%$. The regions that were characterized by the maximum and minimum values of the four considered indicators were identified. The study showed that the territorial location of the regions does not significantly affect the maximum and minimum values of the indicators.

The practical significance of the study for the government is to take into account the gender and territorial features of the development of higher education in Russia. The results of the work can be used in the activities of federal and regional structures related to the support of educational processes, when justifying their planned activities, attracting women and men to higher education. For potential students, data on the gender structure of students studying at higher education institutions in their region of residence may be of particular interest. The new knowledge gained is of interest and can be used in the educational process at universities.

Empirical data in the course of our research described the 4 indicators under consideration for all 82 regions of Russia without exception. Therefore, the study had no limitations and the sample under consideration coincided with the general population. The information used fully corresponded to the actual state of the higher education system in Russia, since it was based on official statistical data, which, according to the results of each of the years under consideration, were presented by all public and private institutions of higher education located in each of the regions.

Further research may be aimed at establishing gender characteristics of the distribution of students enrolled in higher education programs in the regions in 2021 and subsequent years. In addition, an assessment of the 
gender structure of teachers of higher education institutions in the regions of Russia is of interest.

\section{REFERENCES}

ABEL, Jaison; DEITZ, Richard. Do colleges and universities increase their region's human capital? Journal of Economic Geography, v. 12, n. 3, p. 667-691, 2011.

BARRO, Robert; LEE, Jong Wha. A new data set of educational attachment in the world, 1950-2010, NBER Working Paper 15902. 2010.

BASKAKOVA, Marina. Men and women in the education system. Questions of education, n. 1, p. 276-303, 2005.

CHEREDNICHENKO, Galina. Students of the higher school of the RF 2000-2017 (statistical characteristics). Education and science in Russia: the state and potential of development, n. 3, p. 218-241. 2018.

CIRIACI, Daria. Does university quality influence the interregional mobility of students and graduates? The case of Italy, Regional Studies, v. 48(10), p. 1592-1608, 2014.

DZAMPAYEVA, Zhanna. Feminization of higher education: causes and trends. Modern trends in the development of science and technology, $n .2-5, p$. 17-19, 2016.

FEDERAL State Statistics Service. Available at: https://rosstat.gov.ru/ (accessed 20 July 2021).

KARMAEVA, Natalia; KHAVENSON, Tatiana. E.; ILIEVA-TRICHKOVA, Petya. Education and socio-professional status: smoothing inequality among men and women in Russia. Sociological research, n. 3, p. 108-120, 2020.

KONSTANTINOVSKY, David; VOZNESENSKAYA, Elena; CHEREDNICHENKO, Galina. Russian Youth at the Turn of XX-XXI Centuries: Education, Employment, Social Well-being. Moscow: OOO Center for Social Forecasting and Marketing, 548 p., 2014.

MAKAROVA, Svetlana. Gender features of the formation and development of leadership qualities of students during their studies at the university. In the collection: Education: youth, competitiveness. Collection of reports of the International scientific and practical Conference dedicated to the 80th anniversary of the academician of the Russian Academy of Education, Doctor of Philosophy, Professor Shafranov-Kutsev G. F., p. 6873, 2018. 
OFFICIAL statistical information on additional professional and higher education. Ministry of Science and Higher Education of the Russian Federation. Available at: https://minobrnauki.gov.ru/action/stat/highed/ (accessed 20 July 2021).

OSTAPENKO, Anna. Gender asymmetry in professional activity at the university and its causes. Higher education today, n. 3, p. 38-41, 2010.

PEKKARINEN, Tuomas. Gender differences in education, IZA Discussion Papers, n. 6390, Bonn: Institute for the Study of Labor (IZA), 2012.

PINKOVETSKAIA, Iuliia; LEBEDEV, Anton; SLUGINA, Olga; ARBELAEZ CAMPILLO, Diego Felipe; ROJAS BAHAMON, Magda Julissa. Informal Personal Financing of Entrepreneurs: Gender Characteristics. Universal Journal of Accounting and Finance, v. 9(3), p. 442-449, 2021.

PINKOVETSKAIA, Iuliia; SLEPOVA, Vladislava. Estimation of Fixed Capital Investment in SMEs: the Existing Differentiation in the Russian Federation. Business Systems Research, v. 9(1), p. 65-78, 2018.

RYLSKAYA, Elena; MOSHKINA, Lyubov. Gender features of the structure of integral individuality of students. Science for Education Today, v. 10, n. 3, p. $45-64,2020$.

SCIENCE ELECTRONIC LIBRARY. Russian science citation index (RSCI). Available at: https://elibrary.ru/defaultx.asp? (accessed 10 August 2021).

SHISHLOVA, Ekaterina. Gender factor of modernization of university education. Human capital, n. 11-12 (83-84), p. 46-48, 2015.

STOET, Gijsbert; GEARY, David. Gender differences in the pathways to higher education. Proceedings of the National Academy of Sciences, v. 117(25), p. 14073-14076, June, 2020.

TALINA, Irina; KARNAUKHOV, Vladimir. Gender asymmetry in educational and scientific society. Simbirsk Scientific Bulletin, n. 2 (28), p. 55-61, 2017.

WHY do more young women than men go on to secondary education? Education indicators in focus, n. 79, March, OECD, 2021. Available at: https://www.oecd.org/education/why-do-more-young-women-than-men-goon-to-tertiary-education-6f7209d1-en.htm (accessed 29 August 2021). 